\title{
Література:
}

1. Некрасов В.Г. Изношенные автомобильные шины как вторичный енергоресурс. Промышленная энергетика. 1992. Вып. 7. С. 42-45.

2. Рашевский Н.Д., Кроник В.С., Мороз В.А., Неелова И.П. Переработка изношенных автомобильных шин с металлокордом в товарный продукт. Проблемы сбора, переработка и утилизация отходов: Сб. научн. статей. Одесса: ОЦНТЭИ. 2001. С.290-295.

3. Яцун А. В., Коновалов Н. П., Ефименко И. С. Жидкие продукты пиролиза отработанных автомобильных шин под. воздействием СВЧ. Химия твердого топлива. 2013. Вып. 4. С. 60-62.

DOI https://doi.org/10.30525/978-9934-26-046-9-33

\section{THIN-LAYER ORGANOSILICON COATINGS FOR THE PROTECTION OF CELLULOSE-CONTAINING MATERIALS}

\author{
Komakha V. O. \\ Candidate of Technical Sciences (Ph.D.), \\ Associate Professor at the Department of Commodity Science \\ and Customs Affairs \\ Kyiv National University of Trade and Economics \\ Komakha O.S. \\ Candidate of Technical Sciences (Ph.D.), \\ Associate Professor at the Department of Commodity Science \\ and Customs Affairs \\ Kyiv National University of Trade and Economics \\ Kyiv, Ukraine
}

Cellulose fibers in paper are typical natural hydrophilic materials. Cellulose paper is widely used as a packaging material due to its ability to biodegrade, renewable raw materials and low cost. One of the problems of using cellulose-based fibrous material in the packaging industry is its high hydrophilicity, which leads to the absorption of water and moisture, loss of strength and destruction of the material. There are methods of obtaining protective coatings using a variety of substances and materials, in particular 
organic polymers, ceramics and metals, waxes and rosin, modified starches, etc. [1-3].

Polymers are the most common coating materials used to increase the water resistance of paper materials, but their common disadvantage is the need to apply sufficiently thick layers of coating to achieve the desired level of barrier and mechanical properties of paper. Ultimately, such a coating is expensive, not reliable enough, and makes it difficult or even impossible to recycle paper. To reduce the cost of coating, the industry widely uses chemically modified waxes and rosin as a barrier material for coating, but paper with such a coating loses mechanical strength and resistance to breakage, due to the prevention of bonds between reactive groups of adjacent cellulose units. In addition, paper with such coatings is not recyclable [4].

It is well known that paper is a porous-capillary material that contains macropores and micropores. Macropores are cavities between fibers that are filled with air and moisture. Micropores (capillaries) are small cavities of indeterminate shape, as well as cavities that have formed between the walls and inside the cellulose fibers. The porous base of the paper forms microchannels and macrochannels for the penetration of water, which, adsorbed first on the surface of the cellulose-containing fibers, begins to move in all directions, creating a continuous water film that spreads. The material is wetting. The main factor determining the level of susceptibility of cellulose fibers to water adsorption is the presence in their molecular structure of active reactive groups, primarily hydroxyl, carboxyl, carbonyl. Atoms with unshared pairs of electrons contained in these polar groups bind to water molecules with hydrogen bonds. There is a formation of a polymolecular layer of water, and, as a consequence, wetting of the paper surface. Water can break the bonds between adjacent chains of cellulose molecules and thus reduce the stiffness of the fiber and, as a result, the mechanical strength of cellulosic materials.

This problem can be solved by using organosilicon thin-layer coatings based on siloxanes of different composition and structure. The use of organosilicon compounds depending on the type and number of reactive groups near the silicon atom can provide the possibility of chemical interaction with the paper surface and a high degree of adhesive strength. Variation of organic radicals of siloxanes allows to realize high water-repellent properties and, as a result, corrosion resistance and other special properties of cellulose-containing materials, in particular mechanical durability [5-7].

Providing paper with these coatings of high operational reliability in conditions of destructive environmental impact is of particular interest 
among a number of special properties of cellulose-containing materials (electrocardiography, hydrophobicity, heat resistance, etc.), which can be increased using organosilicon compounds. The choice of coating components for the protection of cellulose-containing materials is made taking into account a number of physicochemical features associated with the properties of cellulose-containing substrates, namely: high content of reactive hydroxyl groups in cellulose macromolecules located on almost all parts of their surface; increased sorption capacity for water, and, as a consequence, high hygroscopicity; low resistance to chemical compounds with a $\mathrm{pH}$ other than neutral [8].

Taking into account these features of cellulose-containing materials, the following requirements for organosilicon compounds in the composition of thin-layer protective coatings are formulated: the presence of reactive groups that can chemically interact with the paper surface; minimal corrosion of siloxanes in relation to cellulose; ensuring the protection of paper from a large number of atmospheric and operational factors, the possibility of increasing its mechanical strength [9].

The effective use of thin-layer organosilicon coatings consists in the development of an optimal variant of combining the high reactivity of the porous surface of cellulose-containing materials with siloxanes of various chemical compositions and structures. For this purpose, a scheme for applying a two-layer coating based on tetraethoxysilane is proposed, which is used as an adhesive sublayer. The adhesion sublayer provides an increase in the level of chemisorption activity of the surface of cellulose-containing substrates during their treatment with organosilicon hydrophobicizers, in particular polymethyl- and polyethylhydridosiloxanes. The problem is solved by the fact that the combined thin-layer protective coating for cellulose-containing materials contains an adhesive sublayer based on tetraethoxysilane, as well as a basic protective layer based on polyalkylhydride siloxanes as an outer coating [10].

Samples of unbleached cellulose paper with a combined thin-layer coating were obtained by applying an adhesive sublayer (ethyl silicate hydrolyzate $-98.0 \%$; hydrochloric acid $-2.0 \%$ ), followed by drying in a drying chamber at a temperature of $100^{\circ} \mathrm{C}$ for 1 hour and applying a basic protective layer (thickness $10 \mu \mathrm{m}$ ) $-10 \%$ emulsion of polymethyl- and polyethylhydridosiloxanes (in a ratio of 2:1) in water. The combined application of the adhesive and protective coating allows to obtain on the surface of the paper material a dense hydrophobic film up to $10 \mu \mathrm{m}$ thick, which due to the reaction groups near the silicon atom forms a waterproof plastic protective layer on the surface of the material [10]. 
Based on the results of assessing the hydrophobicity and mechanical strength of paper based on unbleached cellulose with thin-layer silicone coatings, it was established that it is advisable to use organosilicon compounds and a combined method of their application in order to increase the resistance to moisture and mechanical strength of paper both in dry and wet states. The use of combined composite thin-layer coatings allows to increase the mechanical strength of the paper up to $15.4 \%$ and significantly increase the hydrophobicity - the values of the edge angle of wetting with water increase from 60 to 104 degrees [10]. Thus, the proposed coating for cellulose-containing materials is effective against moisture and can significantly increase the mechanical strength of the paper.

\section{References:}

1. Abdelmouleh M. et al. Modification of cellulosic fibres with functionalised silanes: development of surface properties. International Journal of Adhesion and Adhesives. 2004. Vol. 24. Pp. 43-54.

2. Kandelbauer A. On the performance of a melamine-ureaformaldehyde resin for decorative paper coatings. European Journal of Wood and Wood Products. 2010. № 1. Pp. 63-75.

3. Martin T. P. Initiated chemical vapor deposition of antimicrobial polymer coatings. Biomaterials. 2007. Vol. 28. №. 6. Pp. 909-915.

4. Andriot M. Silicones in industrial applications. Inorganic polymers. 2007. Pp. 61-161.

5. Miao C. Cellulose reinforced polymer composites and nanocomposites: a critical review. Cellulose. 2013. Vol. 20. №. 5. Pp. 22212-2262.

6. Missoum K. Nanofibrillated cellulose surface modification: a review. Materials. 2013. Vol. 6. №. 5. Pp. 1745-1766.

7. Salon M. C. B. Studies of interactions between silane coupling agents and cellulose fibers with liquid and solid-state NMR. Magnetic Resonance in Chemistry. 2007. Vol. 45. №. 6. Pp. 473-483.

8. Cappelletto E. Hydrophobic siloxane paper coatings: the effect of increasing methyl substitution. Journal of sol-gel science and technology. 2012. Vol. 62. №. 3. Pp. 441-452.

9. Hongta Yang, Yulin Deng. Preparation and physical properties of superhydrophobic papers. Journal of Colloid and Interface Science. 2008. Vol. 325. № 2. Pp. 588-593.

10. Combined thin-layer organosilicon coating to increase the strength of cellulose-containing materials: patent for utility model № 131021 (Ukraine): C04B 111/27 (2006.01), C04B 41/61 (2006.01). № u201805325; stated 15.05.2018; published 10.01.2019, Bulletin № $1 / 2019$. Р. 4 . 